\title{
THE CHARACTERIZATION OF THE BLOOMING OF WOODBINE LONICERA PERICLYMENUM L.
}

\author{
Jarosław Zieliński \\ Department of Dendrology and Landscape Architecture, Agricultural University, \\ Janosika 8, 71-424 Szczecin, Poland \\ e-mail: jzielinski@agro.ar.szczecin.pl
}

Received: 17.09.2007

$\mathrm{S}$ u m m a r y

This paper presents results of research, conducted in the years 1999-2004, on the influ-ence of cultivation conditions - light exposure and plant top-dressing - on the blooming of woodbine Lonicera periclymenum L. Seven features of the course and rate of blooming were investigated. Cultivation in twilight and using ammonium phosphate as plant top-dressing, among the experimental factors used, were the most profitable to ornamental values con-nected with blooming.

Key words: Lonicera periclymenum, woodbine, blooming, fertilization

\section{INTRODUCTION}

Woodbine is one of the most beautiful native climbers. The research conducted in the eighties and nineties on its occurrence in the Western Pomeranian region and on its variability and phenology showed considerable differentiation of phenotype populations grown in natural stands in north-west Poland $(\mathrm{Z} \mathrm{i} \mathrm{e} \mathrm{-}$ lińs k i, 1996;1997; 1998). It resulted in undertaking further research on the nature of this variability ( $\mathrm{S} \mathrm{mo-}$ lik et al. 2006). Moreover, a question arose: to what degree changes in environmental conditions can affect morphological characteristics of this species, including such factors, so important from the point of view of its cultivation, as the earliness, intensity and length of period of florescence. The findings which will answer this question are presented in this work.

\section{MATERIALS AND METHODS}

The experiment was carried out in the years 19992004 in a plant nursery farm in Szczecin-Zdroje. The experimental material comprised plants reproduced vegetatively from the population 'Nowe Warpno', which was characterized by features typical for the species.
The experiment was established in randomized blocks design. Experimental factors were: light exposure (full insolation - s; twilight, obtained by using shadegiving Isocryl weiß 140/100 with the effect of grading of about $55 \%$ - p; shade obtained by using shade-giving Isocryl grau 140/140 giving the effect of grading of about $70 \%-c)$, and a form of nitric fertil-izer used as plant top-dressing at a dose of $4 \mathrm{~g} \times \mathrm{m}^{-2}$ (ammonium phosphate $-\mathrm{N}_{1}$; ammonium nitrate $-\mathrm{N}_{2}$; calcium nitrate $-\mathrm{N}_{3}$ ).

In the experiment, the number of inflorescences with at least one fully developed flower was counted twice a week. Within the framework of the experiment, the following features were qualified:

1. beginning of blooming, assumed as the number of days from the appearance of the first fully developed flower in the experiment (the first day) to the appearance of the first flower on the plant,

2. length of the blooming period,

3. date of the first peak of blooming, defined as the number of days from the beginning of blooming to the maximum, simultaneous number of inflorescences with at least one fully developed flower,

4. length of the full blooming period, defined as the period with at least $50 \%$ of the si-multaneous number of inflorescences with at least one fully developed inflorescence,

5. total number of flowers on the plant,

6. average number of inflorescences with at least one fully developed flower on the plant, assumed as an arithmetic mean from the number of such inflorescences ob-served during the following measurements,

7. average number of inflorescences with at least one fully developed inflorescence in the full bloom period.

The obtained results were subjected to an analysis of variance. The means were separated by Tuckey's test at a significance level of $p=0.05$. Moreover, taking into account all of the investigated characteristics, the 
test objects were compared one with another to work out a dendrogram of the nearest neighbourhood in the 'Manhattan' urban area. Statistical analysis was performed by STATISTICA.

\section{RESULTS}

The results of the conducted experiment showed that the course of blooming of woodbine was differentiated. The shrubs fertilized with ammonium phosphate, grown in twilight and in full insolation began to bloom earliest, between 19 and 22 May. The shrubs top-dressed with ammonium nitrate, grown in shade and in full insolation, and fertilized with calcium nitrate and grown in twilight, began to bloom latest, between 25 and 31 May - (Figs 1, 2).
The factors used in the experiment also had a significant influence on the blooming period of woodbine. The longest period, on average 50 days, was noted for the shrubs grown in twi-light and top-dressed with ammonium phosphate (Figs 1, 3). However, the shortest pe-riod, on average 30 days, was observed for the shrubs grown in full insolation and fertilized with calcium nitrate. Statistical analysis distinguished two homogenous groups. The shrubs fertilized with ammonium phosphate belonged to the first group, irrespective of light exposure, while the other shrubs - to the second one.

The peak of blooming occurred earliest, on average in 14 days, in the shrubs grown in twi-light and top-dressed with calcium nitrate, and the latest, on average in 25 days - in the shrubs grown in twilight and fertilized with ammonium phosphate. It was noticed that

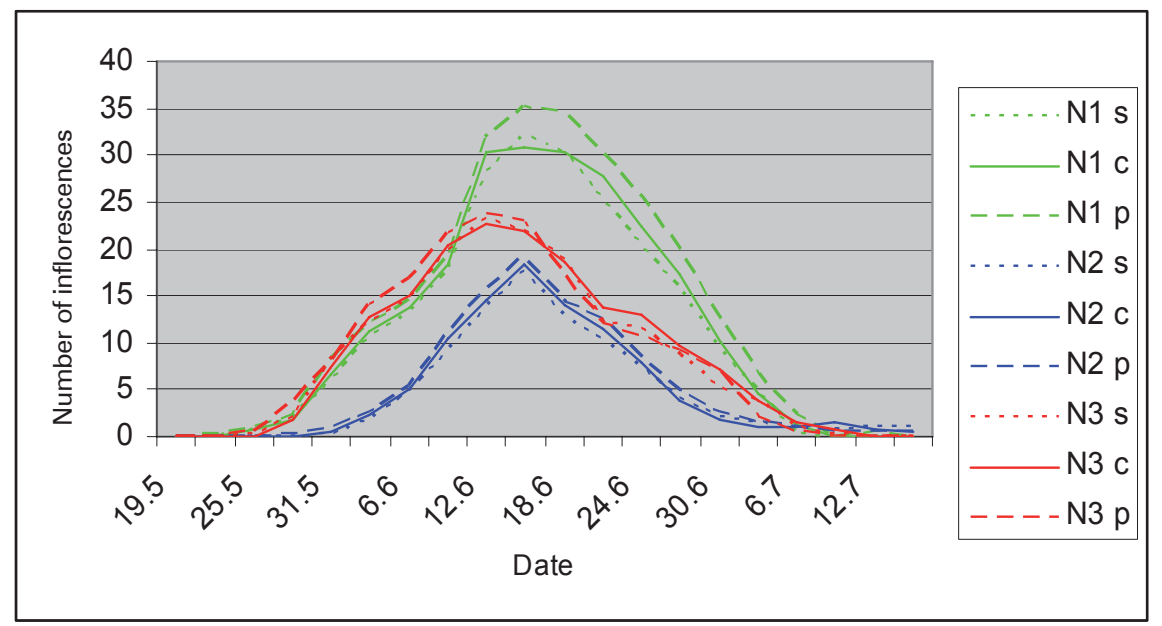

Fig. 1. The influence of the nitrogen form used as plant top-dressing and of light exposure on the dynamics of blooming of woodbine (designations: $\mathrm{N}_{1}, \mathrm{~N}_{2}, \mathrm{~N}_{3}, \mathrm{~s}, \mathrm{c}, \mathrm{p}-$ as in 'Materials and Methods').

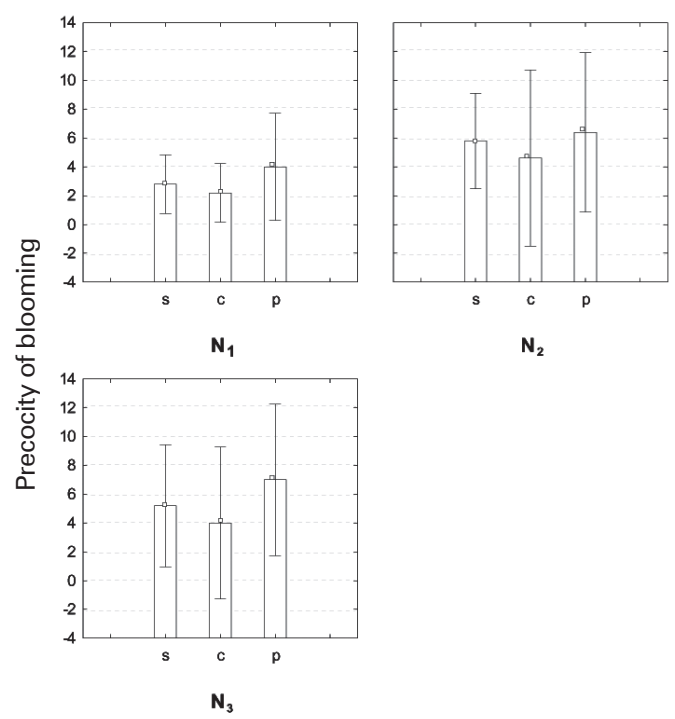

Fig. 2. The influence of the nitrogen form used as plant top-dressing and of light exposure on the earliness of blooming of woodbine (designations: $\mathrm{N}_{1}, \mathrm{~N}_{2}, \mathrm{~N}_{3}, \mathrm{~s}, \mathrm{c}, \mathrm{p}-$ as in 'Materials and Methods'). 


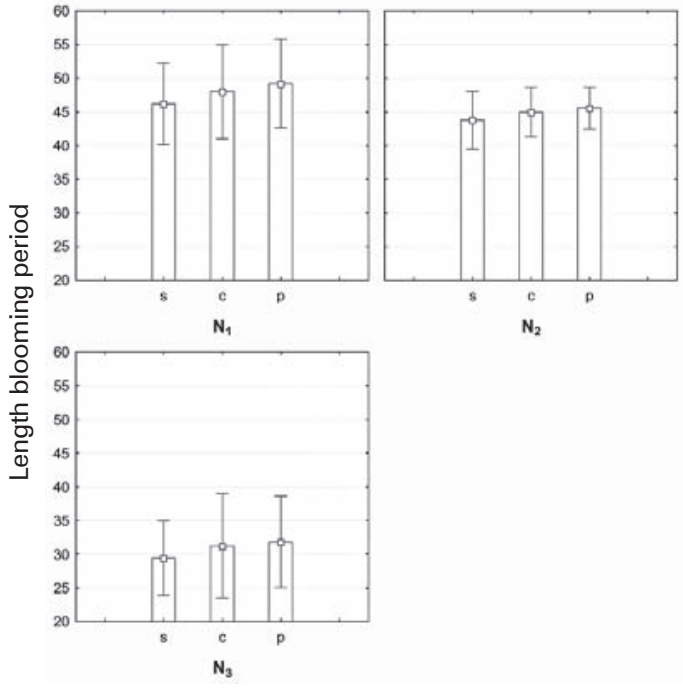

Fig. 3. The influence of the nitrogen form used as plant top-dressing and of light exposure on the length of blooming period of woodbine (designations: $\mathrm{N}_{1}, \mathrm{~N}_{2}, \mathrm{~N}_{3}, \mathrm{~s}, \mathrm{c}, \mathrm{p}-$ as in 'Materials and Methods').

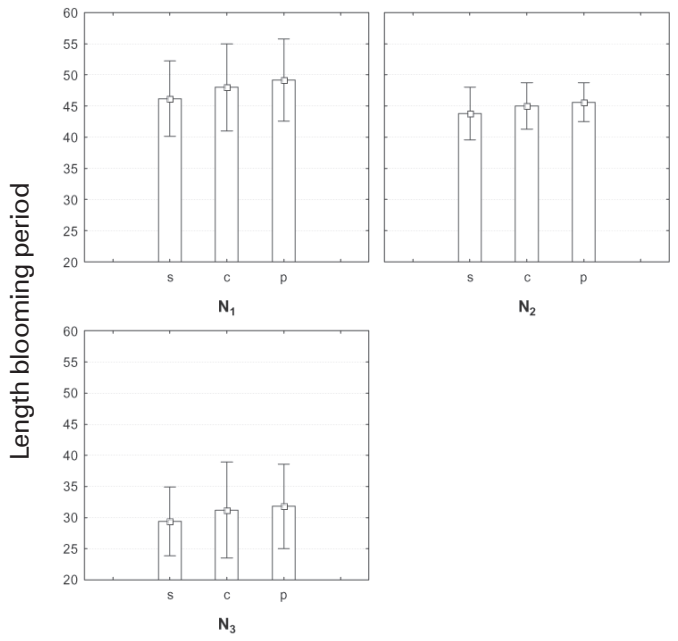

Fig. 4. The influence of the nitrogen form used as plant top-dressing and of light exposure on the peak of the blooming period of woodbine (designations: $\mathrm{N} 1, \mathrm{~N}_{2}, \mathrm{~N}_{3}, \mathrm{~s}, \mathrm{c}, \mathrm{p}-$ as in 'Materials and Methods').

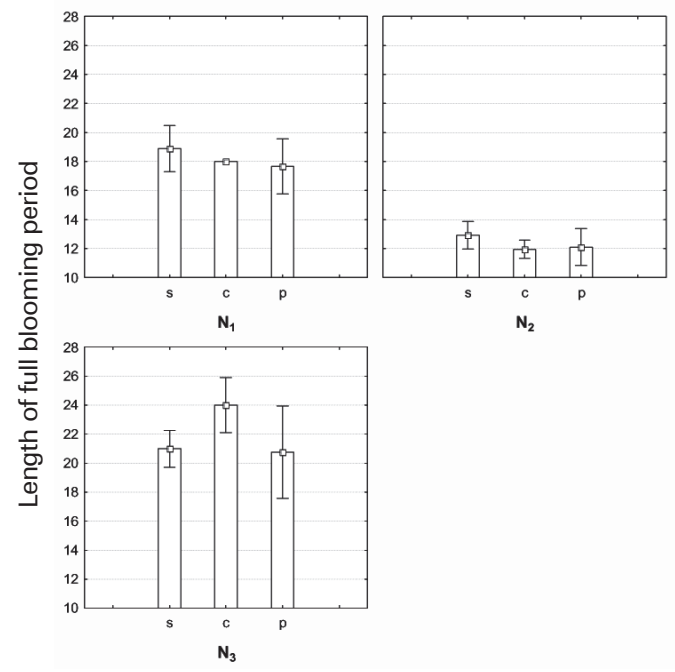

Fig. 5. The influence of the nitrogen form used as plant top-dressing and of light exposure on the length of the full blooming period of woodbine (designations: $\mathrm{N}_{1}, \mathrm{~N}_{2}, \mathrm{~N}_{3}, \mathrm{~s}, \mathrm{c}, \mathrm{p}$ - as in 'Materials and Methods'). 
this occur-rence considerably differed depending on the form of nitric fertilizer and light exposure (Fig. 4). However, because of large differences between the shrubs from the object fertilized with ammonium nitrate, there were no statistically significant differences found.

The factors used in the experiment had a significant influence on the length of the full blooming period (Fig. 5). On average, the shortest period - 12 days - lasted for the shrubs grown in the shade and fertilized with ammonium nitrate, but the longest - 24 days - for the shrubs grown in the shade and fertilized with calcium nitrate. Moreover, it was noticed that the shrubs fertilized with each form of nitric fertilizers created a separate homogenous group.

The experimental factors also had a statistically significant influence on the intensity of blooming (Tab. 1).
Ammonium phosphate top-dressing, especially in case of the plants grown in twilight and shade, had an influence on the increase of the total number of inflorescences and on the mean number of inflorescences in the full blooming period. However, the highest mean number of inflorescences in the whole blooming period was noted for the shrubs fertil-ized with calcium nitrate. It was because these shrubs were characterized by the shortest pe-riod of blooming.

The results of the statistical analysis proved that the factors used in the experiment had an influence on all the analysed features of woodbine blooming. These results showed that the form of nitric fertilizer had a greater influence on the course and intensity of blooming than light exposure (Fig. 6).

Table 1

The influence of the nitrogen form used as plant top-dressing and of light exposure on the intensity of blooming of woodbine (designations: $\mathrm{N}_{1}, \mathrm{~N}_{2}, \mathrm{~N}_{3}, \mathrm{~s}, \mathrm{c}, \mathrm{p}$ - as in 'Materials and Methods').

\begin{tabular}{|c|c|c|c|c|c|c|c|c|c|c|}
\hline \multirow{3}{*}{ Investigated feature } & \multirow{3}{*}{ Year } & \multicolumn{9}{|c|}{ Object } \\
\hline & & \multicolumn{3}{|c|}{$\mathrm{N}_{1}$} & \multicolumn{3}{|c|}{$\mathrm{N}_{2}$} & \multicolumn{3}{|c|}{$\mathrm{N}_{3}$} \\
\hline & & S & $\mathrm{c}$ & $\mathrm{p}$ & $\mathrm{S}$ & $\mathrm{c}$ & $\mathrm{p}$ & s & $\mathrm{c}$ & $\mathrm{p}$ \\
\hline \multirow{3}{*}{$\begin{array}{l}\text { Total number } \\
\text { of inflorescences }\end{array}$} & 1999 & 40.8 & 45.5 & 45.3 & 22.9 & 25.1 & 25.9 & 30.3 & 31.5 & 33.1 \\
\hline & 2000 & 43.0 & 46.8 & 48.7 & 31.5 & 33.5 & 34.5 & 36.8 & 40.5 & 41.1 \\
\hline & 2001 & 44.1 & 46.4 & 50.0 & 32.0 & 28.8 & 33.4 & 36.3 & 38.1 & 39.7 \\
\hline \multirow{3}{*}{$\begin{array}{l}\text { Mean number of } \\
\text { inflorescences in whole } \\
\text { blooming period }\end{array}$} & 1999 & 7.1 & 7.2 & 7.2 & 8.2 & 8.3 & 8.4 & 11.9 & 12.4 & 12.9 \\
\hline & 2000 & 8.3 & 8.5 & 8.8 & 8.7 & 8.9 & 9.3 & 12.3 & 12.5 & 13.3 \\
\hline & 2001 & 8.2 & 7.9 & 8.7 & 8.5 & 9.0 & 9.1 & 12.0 & 12.6 & 13.1 \\
\hline \multirow{3}{*}{$\begin{array}{l}\text { Mean number of } \\
\text { inflorescences in peak } \\
\text { blooming period }\end{array}$} & 1999 & 22.7 & 25.3 & 25.7 & 12.7 & 13.8 & 14.4 & 16.8 & 17.5 & 18.3 \\
\hline & 2000 & 24.2 & 26.0 & 28.0 & 18.6 & 19.8 & 19.7 & 21.6 & 22.5 & 23.4 \\
\hline & 2001 & 24.9 & 25.8 & 27.8 & 17.9 & 16.5 & 18.3 & 20.2 & 22.0 & 21.1 \\
\hline
\end{tabular}

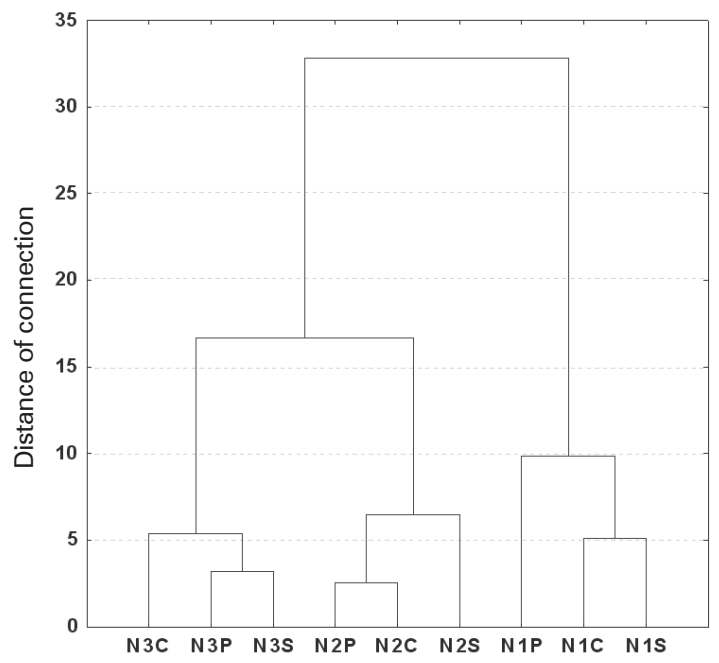

Fig. 6. Dendrogram of the nearest neighbourhood designed on the basis of all analysed features of blooming of woodbine (designations: $\mathrm{N}_{1}, \mathrm{~N}_{2}, \mathrm{~N}_{3}, \mathrm{~s}, \mathrm{c}, \mathrm{p}$ - as in 'Materials and Methods'). 


\section{DISCUSION}

The form of nitric top-dressing and light exposure had a fundamental influence on the blooming dynamics and intensity. The shrubs growing in twilight and in full insolation, and fertilized with ammonium phosphate began the blooming earliest. These shrubs always had the longest period of blooming and the highest total number of inflorescences. The application of calcium nitrate to the shrubs growing in the shade or twilight was the most profitable, tak-ing into account the length of the full blooming period and the mean number of inflorescences in the whole blooming period of woodbine. The shrubs fertilized with this form of nitric dressing, regardless of light exposure, also reached earliest the peak of blooming. A positive influence of nitric fertilization and light conditions on the growth, blooming and biochemical and physiological activity of different plants can be noted in numerous publications concern-ing different plant species (for example, Chał upka and $\mathrm{F}$ ober, 1977; Mynett, 1984; Wesoły et al. 1987; Chałupka, 1993; Dedio and Kozłowski, 1998; Lis-Krzyścin, 1999; Michałojć et al. 2003; Politycka and Golcz, 2004; Golcz and Politycka, 2005; Golcz et al. 2006; Michałojć, 2007), but the aspect of blooming dynamics was not investigated in these research papers. The influence of nitric dressing form on the dynamic of plant blooming is not unequivocal. Results of research show that various plants species respond differently to the fertiliza-

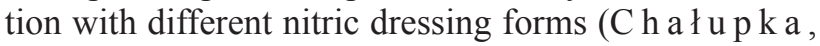
1993; L is - Krzyśc in, 2007).

\section{CONCLUSIONS}

The results of the conducted experiment showed that:

1. the factors used in the experiment had an effect on the course and intensity of bloom-ing of woodbine;

2. among the experimental factors, the form of nitric top-dressing had a greater influ-ence on the course and intensity of blooming;

3. choosing a suitable form of nitric fertilizer gives the possibility of lengthening or in-tensifying blooming of woodbine;

4. the most profitable for decorative values, in terms of woodbine blooming, was the application of calcium nitrate or ammonium phosphate;

5. the most profitable for decorative values, in terms of woodbine blooming, was its cultivation in twilight.

\section{REFERENCES}

Chałupka W. 1993. Fizjologia kwitnienia i obradzania. / Physiology of flowering and fruiting. [In:] Białobok S., Boratyński A., Bugała W. [red.] Biologia sosny zwyczajnej.
/ Biology of Scotch pine. Instytut Dendrologii PAN. Kórnik.

Chałupka W., Fober H. 1977. Studies on the effect of mineral fertilization on flowering and cone and seed crops in Scott pine (Pinus silvestris L.) through an analysis of the litter drop. Arbor. Kórn. 22: 219-235

Dedio I., Kozłowski J. 1998. Wpływ warunków klimatycznych i nawożenia na zawartość kwasu oleanowego w kwiatostanach nagietka lekarskiego (Calendula officinalis L.). / Effects of climatic conditions and fertilization on oleanolic acid content in inflorescences of Pot Marigold (Calendula officinalis L.). Herba Pol. 44 (2): 103-107.

Golcz A., Politycka B. 2005. Effect of nitrogen fertilization on yield and pigment content in the leaves of sweet basil (Ocimum basilicum L.) Herba Pol. 51 (1): 92-93.

Golcz A., Politycka B., Seidler-Łożykowska K. 2006. Wpływ nawożenia azotem i fazy roz-woju roślin na masę oraz jakość liści bazylii wonnej (Ocimum basilicum L.). / The effect of nitrogen fertilization and plant development stage on the weight and quality of the le-aves of sweet basil (Ocimum basilicum L.). Herba Pol. 52 (1, 2): 22-30.

Lis-Krzyścin A. 1999. Effect of nitrogen fertilization on growth and development of Pelargonium $x$ hortorum. I. Effect fo different N levels. Fol. Hort. 11 (1): 45-52.

Lis-Krzyścin A. 2003. Effect of nitrogen fertilization on growth and development of Pelargonium $x$ hortorum. II Effectof differen $\mathrm{N}$ forms. Fol. Hort. 15 (1): 105-112.

Michałojć Z. 2007. Wpływ zróżnicowanego nawożenia azotem i potasem na wzrost, kwitnienie i walory ozdobne gomfreny (Gomphrena globosa L.). / The effect of differentiated nitrogen and potassium fertilization on the growth, flowering and decorative value of gomphrena (Gomphrena globosa L.). Roczn. AR w Poznaniu, 41: 135-139.

Michałojć Z., Konopińska J., Nowak L. 2003. Wpływ nawożenia azotem na wartość dekoracyjną celozji. / The effect of nitrogen fertilization on the decorative value of celosia. Fol. Hort. Sopl. 1: 538-540.

Mynett K. 1984. Goździki. PWRiL. Warszawa.

Politycka B., Golcz A. 2004. Content of chloroplast pigments andantocyanins in the leaves of ocimum basilicum 1. depending on nitrogen doses. Fol. Hort. 16 (1) : 23-29.

Smolik M., Zieliński J., Rzepka-Plevneš D., Adamska K. 2006. Polymorphism of microsatel-lite sequences in morphologically and phenologically different genotypes of Lonicera periclymenum. Jour. of Ford, Agric. Environm. 4 (2): 226-233.

Wesoły W., Urbański K., Barzdajn W. 1987. Effect of Mineral Fertilization on Flowering of Scott Pine (Pinus sylvestris) Grafts. Forest Ecol. Menagm. 19: 191-198.

Zieliński J., 1996. Kwitnące i owocujące okazy wiciokrzewu pomorskiego Lonicera periclymenum L. w woj. szczecińskim. / Flowering and fruiting individuals of woodbine (Lonicera periclymenum L.) in the Szczecin region. In: Zjazd Członków Sekcji Dendrologicznej PTB w Szczecinie 3-5 września 1996: 149-152.

Zieliński J., 1997. Fenologia wiciokrzewu Lonicera periclymenum L. w województwie szczecińskim. / The phenology 
of woodbine (Lonicera periclymenum L.) in the Szczecin region. Zesz. Nauk. AR Szczec. 178: 89-139.

Zieliński J., 1998. Zmienność morfologiczna wiciokrzewu pomorskiego Lonicera periclymenum L. w województwie szczecińskim. / Morphological variability of woodbine (Lonicera periclymenum L.) in the Szczecin region. Folia Univers. Agric. Stetin. 188 (71): 87-114.

\section{Charakterystyka kwitnienia wiciokrzewu Lonicera periclymenum $\mathrm{L}$.}

\section{Streszczenie}

Praca przedstawia wyniki badań, prowadzonych w latach 1999-2004, nad wpływem warunków uprawy - ekspozycji świetlnej i nawożenia pogłównego - na kwitnienie wiciokrzewu pomorskiego Lonicera periclymenum L. Badano 7 cech charakteryzujących przebieg i intensywność kwitnienia. Wykazano statystycznie istotną zmienność badanych cech. Wśród zastosowanych czynników doświadczalnych najkorzystniejszym dla walorów ozdobnych, związanych z kwitnieniem wiciokrzewu pomorskiego, jest uprawa w półcieniu i stosowanie w nawożeniu pogłównym fosforanu amonu. 